ZOOLOGIA 30 (2): 227-237, April, 2013

http://dx.doi.org/10.1590/S1984-46702013000200014

\title{
Revision of the South American Fonckia (Opiliones: Gonyleptidae: Pachylinae) with the description of two new species
}

\author{
Marília Pessoa Silva', Marcos Ryotaro Hara² \& Ricardo Pinto-da-Rocha ${ }^{3}$
}

\author{
${ }^{1}$ Museu de Zoologia, Universidade de São Paulo. Avenida Nazaré 481, 04263-000 São Paulo, SP, Brazil. \\ E-mail: marilia.psilva@yahoo.com.br \\ ${ }^{2}$ Escola de Artes, Ciências e Humanidades, Universidade de São Paulo. Avenida Arlindo Bettio 1000, Ermelino Matarazzo, \\ 03828-000 São Paulo, SP, Brazil. E-mail: marcosrh@usp.br \\ ${ }^{3}$ Departamento de Zoologia, Instituto de Biociências, Universidade de São Paulo. Caixa Postal 11461, 05422-970 São \\ Paulo, SP, Brazil. E-mail: ricrocha@usp.br
}

\begin{abstract}
Fonckia Roewer, 1913 is revised and two new species are described in it: Fonckia contulmo sp. nov., from Monumento Nacional Contulmo, Araucanía, Chile, diagnosed mainly by the enlarged tubercles on the lateral margins of the dorsal scutum, between the median region of scutal area II and the posterior margin of the scutal area III; and Fonckia sosia sp. nov., from Parque Nacional Conguillio, Malleco, Chile, distinguished mainly by the absence of a dorsobasal apophysis on femur IV of the male and a spiniform, enlarged retroapical tubercle on tibia IV of the male. We propose the generic synonymy of Diconospelta Canals, 1934 under Fonckia Roewer, 1913, and the specific synonymy of D. vazferreirae Mello-Leitão, 1946 under F. processigera (Sørensen, 1902). We also propose the new combination $F$. gallardoi (Canals, 1934) comb. nov. As a consequence, the genus is henceforth composed of four species. We present an identification key for the species of Fonckia, as well as diagnoses and a discussion of the Chilean Pachylinae.
\end{abstract}

KEY WORDS. Chile; harvestmen; Neotropics; systematic; taxonomy.

The Chilean opilionid fauna is composed of about 90 endemic species, although some of its components also occur in the Argentinean side of the southern Andean Cordillera (KURY 2003). The Chilean regions with rather expressive numbers of species are the Región de Los Lagos (38 species) and Región del Bío-Bío (33 species) (Kury 2003). The remaining regions have noticeably less species, some of them with virtually no records at all. Laniatores, the most diverse suborder in the Neotropics (PInTo-DA-Rocha et al. 2007), are also the best represented in Chile in terms of numbers of species. Most of the Chilean laniatorids are either included in the Triaenonychidae or Gonyleptidae. Among the Chilean Gonyleptidae, Pachylinae, with 55 species, is the most diverse.

Upon examining the endemic southern Andean Pachylinae, we noticed a remarkable resemblance among species of two genera, Fonckia Roewer, 1913 and Diconospelta Canals, 1934. This resemblance had been already pointed out by AcosTA \& MAURY (1998), who suggested that F. processigera and D. gallardoi could be synonymous. However, both species were described based on specimens of different sexes and for that reason their synonymy has yet to be established. SøRENSEN (1902) described Gonyleptes processiger and placed it in Gonyleptidae. Later, RoEwER (1913) created Fonckia for this species, keeping it in Gonyleptinae. Mello-Leitão (1931), following the trend in harvestmen systematics of his time, which was based on the analysis of only a few characteristics (for details see BRAGagnolo \& PINTO-DA-ROCHA 2009,
DaSilva \& Gnaspini 2009, DaSilva \& PinTo-Da-Rocha 2010, Hara \& PINTO-DA-Rocha 2010 and references therein), suggested that Fonckia is related to the gonyleptid genera Progonyleptoides Roewer, 1917, Stephanocranion Mello-Leitão, 1931 (junior synonym of Gonyleptellus Roewer, 1930 according to KuRY (2003)) and the Peruvian genera Lucma Roewer, 1930, Huasampillia Roewer, 1913 (senior synonym of Lucma according to SOARES \& SoAres (1949)) and Huadquina Roewer, 1930. Canals (1934) described Diconospelta for D. Gallardoi (sic) in Pachylinae. MelloLeitÃo (1946) described D. vazferreirae, based on a female. RINGUELET (1959) corrected the spelling for D. gallardoi and described the female of that species. Acosta \& MAURY (1998) first noted the resemblance between Fonckia and Diconospelta, indicating D. gallardoi as a junior synonym of $F$. processigera. However, because the synonymy was neither formally indicated (i.e. using "new synonymy" or equivalent statement) nor justified, it has not been subsequently recognized, and both species are listed as valid in Kury's catalog, which first moved Fonckia to the Pachylinae (KuRY 2003).

In a recent collecting expedition to Chile, the third author and colleagues collected many pachylines, and among them, previously undescribed species that could be either allocated into Fonckia or Diconospelta. In order to clarify their taxonomic placement, we herein revise the two genera. In addition, we provide an identification key, diagnoses and a discussion of the relationships among Fonckia and other Chilean Pachylinae genera. 


\section{MATERIAL AND METHODS}

We examined material from the following depositories: Museo Argentino de Ciencias Naturales (MACN); Museo Nacional de Historia Natural de Chile (MNHNCL); Museu Nacional (MNRJ); Museu de Zoologia da Universidade de São Paulo (MZSP); Museo Nacional de Historia Natural de Montevideo (URMU); California Academy of Sciences (CAS); Institut für Systematische Zoologie, Museum für Naturkunde der Humboldt-Universität zu Berlin (ZMB); and American Museum of Natural History (AMNH).

We used a stereomicroscope with camera lucida (LEICA MZ-APO) to illustrate the external morphology. We prepared the male genitalia according to PINTO-DA-Rocha $(1997,2002)$ for illustrations using a camera lucida attached to a compound microscope (ZEISS AXIOSKOPE), and to take pictures using a LEICA LEO 440 scanning electron microscope, housed at the MZSP. In the descriptions, we used the nomenclature of AcosTA et al. (2007) with some modifications tailored to the group. The following abbreviations were used in the descriptions: (cat) catalogue, (cit) citation, (desc) description, (DSL) dorsal scutum length, (DSW) dorsal scutum maximum width, (FIV) length of femur IV, (PpL) pedipalpal femur length, (PrL) prosoma length, (PrW) prosoma maximum width, (rdes) redescription, (syst) systematic discussion. We present only the different characteristics from the male in the (re)description of females. Generic characteristics are not repeated in the specific descriptions. The measurements are in millimeters.

\section{TAXONOMY}

\section{Fonckia Roewer, 1913}

Fonckia Roewer, 1913: 175 (desc); 1923: 466 (rdes); Mello-Leitão, 1926: 25 (key); 1931: 124 (syst); Roewer, 1930: 343 (key); Mello-Leitão, 1932: 245 (rdes); Mello-Leitão, 1935: 103 (syst); Canals, 1936: 69 (cit); Soares \& Soares, 1949: 166 (cat, rdes); Cekalovic, 1985: 13 (cat); Acosta \& Maury, 1998: 580 (cit); Kury, 2003: 170 (cat). (type species: Gonyleptes processigerus Sørensen, 1902, by monotypy).

Diconospelta Canals, 1934: 3 (desc); Mello-Leitão, 1935: 103 (syst); Soares \& Soares, 1949: 165 (cat, rdes); Ringuelet, 1959: 398 (rdes); Cekalovic, 1985: 13 (cat); Kury, 2003: 159 (cat). (type species: Diconospelta gallardoi Canals, 1934). Syn. nov.

Diagnosis. Fonckia Roewer, 1913 resembles many Pachylinae genera such as Discocyrtus Holmberg, 1878, Eubalta Roewer, 1923, Hypophyllonomus Giltay, 1928, Ogloblinia Canals, 1933, Singram Mello-Leitão, 1937, Juticus Roewer, 1943, among others, which presents four scutal areas (classic diagnosis of the subfamily) and only the scutal area III is armed with a pair of enlarged spines. Fonckia can be distinguished from those genera by the following combination of characters: unarmed ocularium, posterior corners of dorsal scutum with cluster of tubercles (absent in $F$. processigera), male trochanter IV prolaterally with a conical, short, blunt median apophysis and a conical, long, blunt apical apophysis curved dorsad.

Redescription. Male: Dorsum. Anterior margin of prosoma with median frontal hump, smooth or with sparse granules. Ocularium unarmed. Dorsal scutum (except for anterior margin) densely granulated, with five transversal grooves delimiting four scutal areas (scutal groove IV conspicuous only in the middle in $F$. processigera, F. contulmo sp. nov. and F. sosia sp. nov.). Scutal area I divided by a longitudinal median groove in right and left halves. Lateral margins of dorsal scutum with a row of whitish to beige tubercles from ocularium to groove II. Scutal area III with a pair of paramedian spines of large base and blunt apex. Posterior margin of dorsal scutum, free tergites I-III each one with a row of tubercles. Chelicerae. Isomorphic in males and females, with 1 small tubercle or smooth on bulla. Pedipalps. Coxa smooth or with sparse tubercles; trochanter with 1-2 ventral tubercles. Femur with 1-5 small ventral tubercles on basal half, 1 retrolateral subapical tubercle; patella-tarsus dorsally with tubercles; tibiatarsus with unbranched setae. Legs. Coxa I-III each one with 1 prolateral, 1 retrolateral apophyses (retrolateral apophysis of coxa II fused at apex with prolateral apophysis of coxa III); IV with small setiferous tubercles and a long prolateral apical apophysis, its apex slightly curved ventrally. Trochanters-tibiae I-IV tuberculated. Trochanter IV with prolateral apophyses. Femora I-II substraight; III-IV straight or slightly curved, ventrally with two conspicuous rows of tubercles, armed ventro-apically with enlarged spiniform tubercles on apex or distal 1/3. Tibia III ventrally with two rows of enlarged, pointed tubercles increasing in size apically, 2 apical spines; IV idem, but on distal $1 / 2$ or $1 / 3$. Penis. Ventral plate reaching subdistal part of glans, subrectangular with a median lateral constriction, its distal margin straight or slightly concave, distal half thicker than basal half in lateral view; 4-5 pairs of distal setae; 1 pair of median small setae (except $F$. gallardoi); 1-3 pairs of basal setae. Glans projected dorsally; stylus cylindrical and long, with ventral projections on distal $1 / 2$ to $1 / 4$; ventral process cylindrical, apex truncated with small ventral projection. Stylus and ventral process curved dorsally.

Female. Similar to male, but coxa IV with spiniform prolateral apical apophysis smaller than male. Trochanter IV without prolateral apophyses (except in F. sosia sp. nov., which has both prolateral apophyses, but smaller than in male). Femora-tibiae III-IV like male (except in $F$. processigera, which leg III is smooth and femur-tibia IV with armature less developed than in male). Female of $F$. contulmo sp. nov. unknown.

\section{Key to the males of Fonckia}

1. Femur IV with a dorso-basal apophysis directed upwards, with curved apex (Fig. 9) .................................... F. gallardoi

1 '. Femur IV without dorso-basal apophysis (Figs 4, 14, 19) ... 2

2. Trochanter IV with one thin, long (length approximately to the width of the basal portion of femur IV) retrolateral apical acute enlarged tubercle; apexes of two prolateral apophyses touching each other (Figs 14, 15) ................ F. processigera 
2 '. Trochanter IV without or with small (length approximately up to $1 / 2$ of the width of basal portion of femur IV) retrolateral apical tubercle; apexes of two prolateral apophyses not touching each other (Figs $4,5,19,20) \ldots 3$

3. Femur IV swollen at basal $1 / 2-1 / 3$ and densely covered with enlarged tubercles, largest ones on prolateral face (Figs 4 , 5) ... F. contulmo sp. nov.

3'. Femur IV not swollen basally and without enlarged tubercles on prolateral face (Figs 19, 20) F. sosia sp. nov.

\section{Fonckia contulmo sp. nov.}

Figs 1-5, 21, 22, 33

Diagnosis. Fonckia contulmo sp. nov. resembles F. gallardoi and F. sosia sp. nov. by: posterior corners of dorsal scutum with a cluster of tubercles (Fig. 1) and male patella IV with at least an enlarged, pointed proventral apical tubercle (Fig. 5). Fonckia contulmo sp. nov. can be distinguished from those species by: enlarged tubercles on lateral margins of dorsal scutum between median region of scutal area II and posterior margin of scutal area III (Fig. 1); male femur IV swollen at basal 1/2-1/3, which is densely covered with enlarged tubercles, largest ones on prolateral face (Figs 4 and 5); and penis ventral plate with distal bifid setae and three pairs of basal setae (Figs 21 and 22).

Description. Male (holotype): Measurements. DSL 6.3, DSW 6.0, PrL 2.0, PrW 3.0, PpL 2.0, FIV 4.8. Dorsum (Fig. 1). Anterior margin of prosoma with tubercles on its entire extension. Ocularium tuberculate. Prosoma anteriorly with sparse granules. Scutal area III with a parallel pair of paramedian spines of tuberculate base and apex slightly curved backwards. Scutal groove IV conspicuous only posteriorly between pair of spines on scutal area III. Incomplete scutal area IV divided in right and left halves. Lateral margin of dorsal scutum with a row of 22-23 beige tubercles from ocularium to anterior region of scutal area II and another row of 12-16 tubercles (same color as dorsal scutum) from median region of scutal area II to posterior margin of scutal area III. Corners of posterior margin of dorsal scutum and free tergites I-II with a cluster of whitish tubercles among other smaller ones. Venter. Coxae I-IV uniformly covered with small tubercles. Chelicerae. Segment I with 1 tubercle on bulla; segment II with 7 teeth; III with 6 teeth. Pedipalps. Coxa with 1 ventro-median tubercle; trochanter with 2 ventro-median tubercles. Femur with 3 small ventral tubercles on basal half. Tibial setation: mesal iIiII/iIII; ectal Ii. Tarsal setation: mesal III; ectal IiII/III. Legs (Figs 2-5). Coxa II with 1 tubercle on the base of retrolateral apophysis; IV with prolateral apical apophysis wrinkled on retrolateral median margin. Trochanters I-II with 1 ventro-median slightly enlarged tubercle; IV prolaterally with 1 conical median apophysis, 1 enlarged apical apophysis, its apex curved anteriorly; retrolaterally with 1 conical, enlarged apical tubercle. Femur III (Fig. 3 ) with two ventral rows of tubercles increasing in size apically, becoming pointed; IV basal 1/2-1/3 swollen (Figs 4 and 5), this part densely covered with enlarged tubercles (proventral ones largest), one pro- and retroventral row of round, enlarged tubercles increasing in size apically, 2 ventro-apical spines. Patella IV with 1 proventral apical enlarged tubercle (Fig. 5). Tibia IV with 2 ventro-apical spines (Fig. 5). Tarsal segmentation: 5, 7-8, 6, 6. Penis (Figs 21 and 22). Ventral plate with 5 pairs of distal bifid setae; 3 pairs of basal bifid setae. Glans stylus with ventral projections on subdistal $1 / 4$. Coloration. Dorsum dark brown with some beige tubercles on lateral margin and corners of posterior margin of dorsal scutum and corners of free tergites I-II. Some light brown tubercles on trochanter-femur IV. Pedipalp yellow with some darkened spots. Female. Unknown.

Type material. ChILE, IX Región de Araucanía: Monumento Nacional Contulmo, 12.XII.2010, F. Marques, F. Cádiz \& F. Carbayo leg., male holotype (MNHNCL); Cautin, Fundo Las Selva, $\mathrm{N}$ of Temuco and NW of Nueva Imperial, 750 m, 16-20.II.1981, L.E. Pena leg., 2 males paratypes (AMNH).

Type locality (Fig. 33). Chile, IX Región de Araucanía: Monumento Nacional Contulmo.

Etymology. In reference to the type locality, the beautiful Parque Nacional Contulmo. The specific epithet means passageway in the Mapudungun language.

\section{Fonckia gallardoi (Canals, 1934) comb. nov. \\ Figs $6-10,23,24,31-33$}

Diconospelta Gallardoi Canals, 1934: 4, fig. 1 (desc); Soares \& Soares, 1949: 165 (cat, rdes) (Male holotype, MACN 7160, examined).

Diconospelta gallardoi: Ringuelet, 1959: 398, figs XVIII-3, 4 (rdes); Galiano \& Maury, 1979: 318 (cit); Acosta \& Maury, 1998: 580 (cit); Kury, 2003: 159 (cat).

Diagnosis. Fonckia gallardoi resembles F. contulmo sp. nov. and F. sosia sp. nov. by: posterior corners of dorsal scutum with a cluster of tubercles (Fig. 6) and male patella IV with at least an enlarged, pointed proventral apical enlarged tubercle (Figs 9 and 10). Fonckia gallardoi can be distinguished from those species by: prolateral apical apophysis on male trochanter IV enlarged, long (length longer than this podomere width) and curved; and presence of a dorso-basal apophysis on male femur IV (Fig. 9).

Redescription. Male (MZSP 36829): Measurements. DSL 7.5, DSW 6.9, PrL 2.5, PrW 3.2, PpL 2.0, FIV 5.5. Dorsum (Fig. 6). Prosoma anteriorly with sparse granules. Ocularium with 18 tubercles. Scutal area III with a pair of paramedian divergent spines slightly curved backwards. Lateral margin of dorsal scutum with a row of 27-30 beige tubercles from ocularium to anterior region of scutal area II and cluster of 18-21 tubercles next to scutal area III-IV. Corners of posterior margin of dorsal scutum and free tergite I with a cluster of tubercles. Anal operculum tuberculate. Venter. Coxa I with a median row of 7 enlarged tubercles and 3 apical ones; II-IV, stigmatic area 
granulated. Chelicerae. Segment I with 1 tubercle on bulla; II with 5 teeth; III with 4 teeth. Pedipalps. Coxa smooth; trochanter with 2 ventral tubercles. Femur with 3-4 ventral tubercles on basal 1/2. Patella with 3-4 dorsal tubercles. Tibia with 4 dorsal tubercles; tibial setation: mesal IiI, ectal Ii. Tarsal setation: mesal Iii, ectal II. Legs (Figs 7-10). Coxa II retrolateral apophysis bifid, its prolateral branch pointing towards posterior opening of ozopore and retrolateral branch fused with prolateral apophysis of coxa III (as in generic redescription); IV densely granulate (except for apophysis), its apophysis oblique, curved backwards, with 1 enlarged tubercle on ventral apex. Trochanter III with 1 enlarged retrolateral tubercle; IV prolaterally with 1 conical median apophysis, 1 enlarged, very long (length longer than this podomere width), robust apical apophysis, its apex curved anteriorly (Fig. 9). Femur III (Fig. 8) with two ventral rows of tubercles increasing in size apically, becoming pointed; IV (Fig. 10) with a dorso-basal apophysis curved outwards, ventrally with 1 enlarged ventro-basal tubercle, two rows of tubercles increasing in size apically, prolateral largest, 2 apical spines. Patella IV with 4 proventral enlarged tubercles increasing in size apically from basal half (the apical largest and pointed, see Fig. 10). Tibia IV ventrally with two rows of tubercles increasing in size apically on distal 1/3, 2 apical spines (Fig. 10). Tarsal segmentation: 5, 7, 6, 6. Penis (Figs 23 and 24). Ventral plate with 4 pairs of distal unbranched setae, 3 pairs of rounded projections distal ventrally, 2 pairs of basal setae, without pair of median short setae. Glans stylus with ventral projections on distal 1/3. Coloration (Fig. 31). Dark brown, posterior region of lateral margin of dorsal scutum, coxa-trochanter IV apophysis and femur-tibia I-IV black. Apex of pair of paramedian spines on scutal area III yellowish. Trochanter I-III, metatarsus-tarsus yellowish-green. Enlarged tubercles on lateral margin and posterior corners of dorsal scutum whitish. Size variation of males $(n=4)$. DSL 5.46.0, DSW 5.4-5.5, PrL 1.8-2.0, PrW 2.8-3.0, PpL 1.6-1.9, FIV 4.0-4.5. Female (MZSP 36931). Measurements. DSL 6.1, DSW 5.7, PrL 2.2, PrW 2.7, PpL 1.3, FIV 3.9. Prosoma anterior region densely granulate. Tubercles on lateral margin and corners of posterior margin of dorsal scutum close to each other. Femora III-IV, patella IV and tibia IV with ventral rows of enlarged tubercles. Tarsal segmentation: 5, 7-8, 6, 6. Coloration similar to male (Fig. 32). Size variation of females $(\mathrm{n}=7)$. DSL 5.7-6.8, DSW 5.5-6.0, PrL 1.7-2.3, PrW 2.8-3.0, PpL 1.5-3.0, FIV 3.54.0 .

Examined material. Chile, X Región de Los Lagos: Osorno, Parque Nacional Puyehue, Salto Del Indio, R. Pinto da Rocha, F. Cádiz L. \& D. Cádiz L. leg., 20.I.2010, 2 males, 2 females (MZSP 36931); idem, F. Cádiz L. \& D. Cádiz leg., 20.I.2010, 1 male (MZSP 36829); idem, near Aguas Calientes, L. Almeida \& C. Griswold leg., 1 female (IBSP 10513); Parque Nacional Puyehue: S.E. Lew, K.W. Will leg., 15.I.2003, 1 male (CAS 9016532). CHILE. IX Región de Araucanía: Puesco, Parque Nacional Villarrica, R. Pinto da Rocha, F. Cádiz L. \& D. Cádiz L. leg., 24-25.I.2010, 4 females (MZSP 39039). ArgentinA, Rio Negro: Nahuel Huapí, J.B. Daguerre leg., II.1934 (MACN 7160, holotype).

Type locality (Fig. 33). Argentina, Rio Negro: Nahuel Huapí.

\section{Fonckia processigera (Sørensen, 1902)}

Figs $11-15,27,28,33$

Gonyleptes processiger Sørensen, 1902: 25 (desc); (male holotype ZMB 8397, examined).

Fonckia processigera: Roewer, 1913: 175, fig. 74 (rdesc); 1923: 466, fig. 585 (rdes); Soares \& Soares, 1949: 166 (cat, rdes); Moritz, 1971: 208 (cat); Cekalovic, 1985: 13 (cat, dist); Acosta \& Maury 1998: 580 (cit); Kury, 2003: 170 (cat).

Fonckia prossigera [sic]Canals, 1936: 69 (cit).

Diconospelta vazferreirae Mello-Leitão, 1946: 4 (desc); Soares \& Soares, 1949: 165 (rdes); Cekalovic, 1985: 13 (cat, dist); Kury, 2003: 159 (cat); (female holotype, URMU, examined). Syn. nov.

Diagnosis. Fonckia processigera can be easily distinguished from the other three species of Fonckia by lacking a cluster of tubercles on the corners of the posterior margin of the dorsal scutum (Fig. 11), and ventral plate of penis with one pair of basal setae (other species of the genus with two to three pairs of setae, see Figs 27 and 28).

Redescription. Male (MZSP 36853): Measurements. DSL 9.0, DSW 7.4; PrL 3.0, PrW 4.0, PpL 1.6, FIV 8.1. Dorsum (Fig. 11). Anterior margin of prosoma with prominent median frontal hump and sparse small tubercles. Ocularium tuberculate. Scutal area III with a pair of paramedian spines slightly divergent and curved backwards. Scutal groove IV conspicuous only posteriorly between pair of spines on scutal area III. Lateral margin of dorsal scutum with a row of 12-14 beige tubercles from ocularium to anterior region of scutal area I. Anal operculum with two transversal rows of tubercles. Venter. Coxa I with median row of 4-5 setiferous tubercles and 3 posterior ones; II-IV densely covered with setiferous tubercles. Stigmatic area with sparse tubercles. Chelicerae. Segment I with 1 tubercle on bulla; II with 6 teeth; III with 5 teeth. Pedipalps. Coxa tuberculate; trochanter with 1 ventro-apical tubercle. Femur with 1 ventro-basal tubercle. Patella with 12 dorsal tubercles. Tibia with 11 dorsal tubercles, tibial setation: mesal II/ iI; ectal I. Tarsus with 4 dorsal tubercles, tarsal setation: mesal IIi; ectal IIi. Legs (Figs 12-15). Coxae I-II additionally with 1 prolateral tubercle and 1 enlarged retrolateral one; II additionally with 1 enlarged median tubercle; IV covered with setiferous tubercles, its apophysis almost transversal (in relation to the body main axis) and curved ventrally. Trochanters I-III dorsally smooth; I-II with 1 ventro-median enlarged tubercle; III with 1 prolateral tubercle (Fig. 12); IV prolaterally with 1 conical median apophysis, 1 enlarged, long, robust apical apophysis, apex of these two apophyses touching each other, 1 enlarged apical tubercle; retrolaterally with 1 enlarged, long, pointed tubercle. Femora III-IV (Figs 13 and 15) ventrally with two rows 

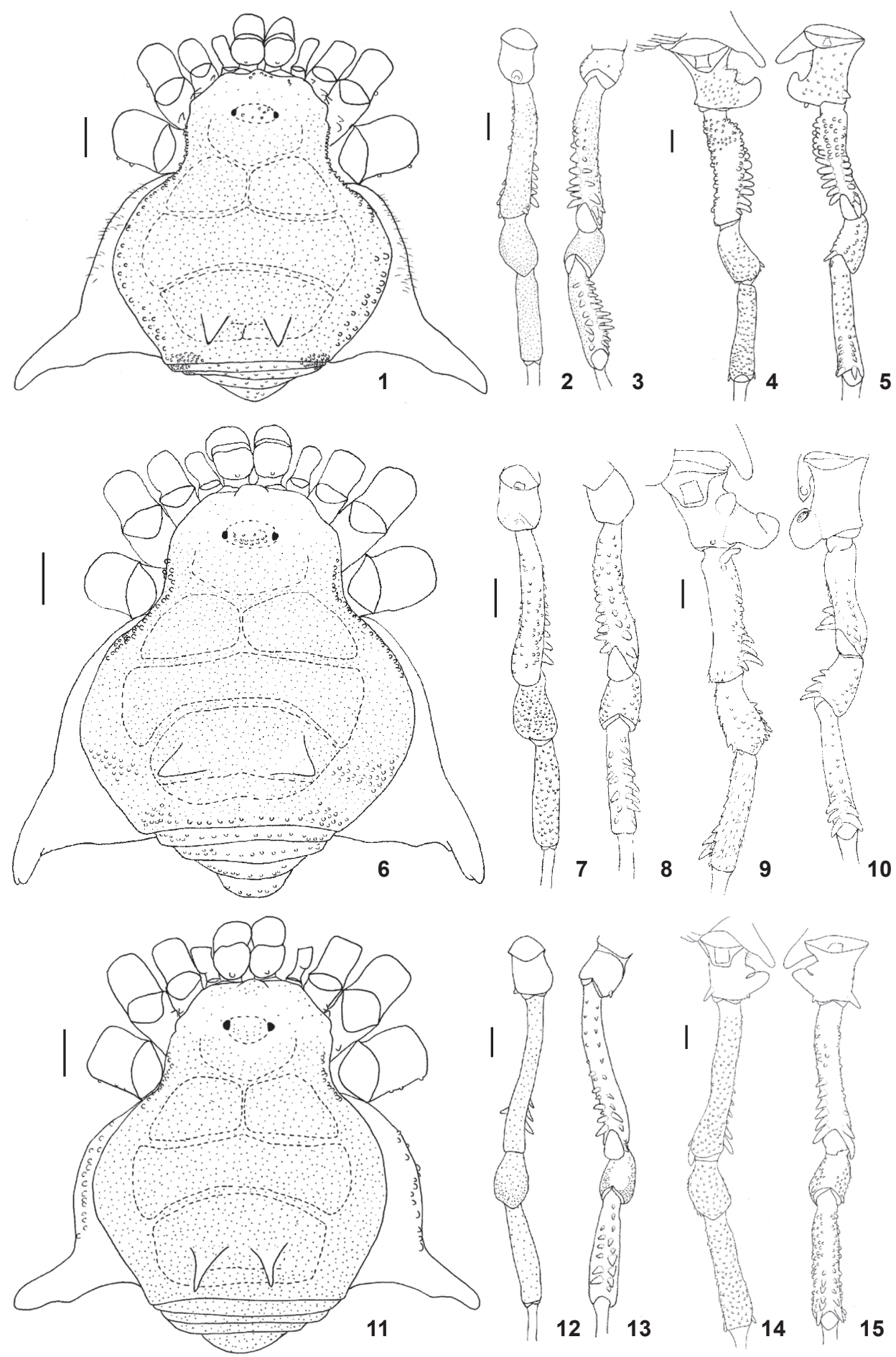

Figures 1-15. (1-5) Fonckia contulmo sp. nov., male holotype (MNHNCL): (1) dorsal habitus; (2) right trochanter-tibia III, dorsal view; (3) idem, ventral view; (4) right trochanter-tibia IV, dorsal view; (5) idem, ventral view. (6-10) Fonckia gallardoi, male (MZSP 36829): (6) dorsal habitus; (7) right trochanter-tibia III, dorsal view; (8) idem, ventral view; (9) right trochanter-tibia IV, dorsal view; (10) idem, ventral view. (11-15) Fonckia processigera, male (MZSP 36853): (11) dorsal habitus; (12) right trochanter-tibia III, dorsal view; (13) idem, ventral view; (14) right trochanter-tibia IV, dorsal view; (15) idem, ventral view. Scale bar: $1.0 \mathrm{~mm}$. 
of tubercles increasing in size apically, 2 apical spines. Patella IV with enlarged tubercles apically (Fig. 14), 1 proventral blunt and largest one (Fig. 15). Tibia I-II smooth; III-IV ventrally with two rows of tubercles increasing in size apically on distal $1 / 2$ (Figs 13 and 15); IV with 1 subapical retrolateral spine. Metatarsi III-IV thickened. Tarsal segmentation: 5, 7, 6, 6. Penis (Figs 27 and 28). Ventral plate distal margin straight; 4 pairs of distal unbranched setae, 2 pairs of rounded projections distal ventrally, 1 pair of basal setae. Glans stylus with ventral projections on distal 1/3. Coloration. Brown, grooves and lateral margins of dorsal scutum dark brown. Legs I-III, metatarsus-tarsus IV yellowish. Enlarged tubercles on lateral margin of dorsal scutum beige. Size variation of males $(n=3)$. DSL 6.9-7.5, DSW 6.06.7; PrL 2.2-2.8, PrW 3.2-3.9, PpL 2.0-2.1, FIV 6.2-7.0. Female (MZSP 39012). Measurements. DSL 8.1, DSW 7.1, PrL 2.6, PrW 3.5, PpL 1.9, FIV 5.9. Scutal area IV divided in right and left halves. Chelicerae with segment I smooth; II with 4 teeth. Pedipalpal tibial setation: mesal iI/IIi, ectal Ii. Coxa IV with spiniform prolateral apical apophysis longitudinally depressed, its length slightly shorter than podomere apical width, smaller than in male. Trochanter IV with long, enlarged retroapical tubercle. Femora-tibiae III-IV unarmed, covered with similar sized tubercles. Tarsal segmentation 5, 8, 6, 6. Size variation of females $(\mathrm{n}=6)$. DSL 7.3-8.0, DSW 6.5-7.2; PrL 2.1-2.5, PrW 3.4-3.8, PpL 1.8-2.0, FIV 6.0-6.5.

Examined material. Chile, X Región de Los Lagos: Chiloé, Parque Tantauco, F. Cádiz L. leg., VII.2010, 1 male (MZSP 36853); Osorno, La Union (MNRJ 4742); Osorno, Barra Del Rio Bueno, R. Vaz Ferreira leg., II.1945, 2 females (URMU holotype); Osorno,
Pucatrihue, 11.XII.1980, 1 female (AMNH); Chiloé, P.N. Chiloé, Isla Chiloé, L. Almeida et al. leg., 3.XII.2010, 2 females (IBSP 10535); Chiloé, Dalcahue, L Peña leg., 17-31.I.1962, 1 male (MCZ AK 003); P.N. Alerce Andino, F. Marques, F. Cádiz L. \& F. Carbayo leg., 15.XII.2010, 2 females (MZSP 39012); Llanquihue, Puerto Montt, E. Maury leg., 7-8.XII.85, 1 male (MACN AK 073).

Type localities of: 1) Fonckia processigera: CHILE, X Región de Los Lagos: Llanquihue, Puerto Montt (Fig. 33); and 2) Diconospelta vazferreirae: CHILE, X Región de Los Lagos: Osorno, Barra del Río Bueno.

\section{Fonckia sosia sp. nov.}

Figs 16-20, 25, 26, 29, 30, 33

Diagnosis. Fonckia sosia sp. nov. resembles F. gallardoi and Fonckia contulmo sp. nov. by: posterior corners of dorsal scutum with a cluster of tubercles and male patella IV with at least an enlarged, pointed proventral apical enlarged tubercle. Fonckia sosia sp. nov. can be distinguished from those species by the combination of the following features: pair of paramedian spines on scutal area III with dark apex; male trochanter IV with prolateral apical apophyses less developed (in relation to F. gallardoi and F. contulmo sp. nov.); male femur IV without dorso-basal apophysis; male tibia IV with spiniform, enlarged retroapical tubercle.

Description. Male (holotype): Measurements. DSL 6.2, DSW 5.7, PrL 2.1, PrW 3.1, PpL 1.6, FIV 4.5. Dorsum (Fig. 16). Anterior margin of prosoma covered with granules and 3-5 tubercles on each side. Ocularium with tubercles on median and posterior region. Prosoma anteriorly with sparse granules. Scutal
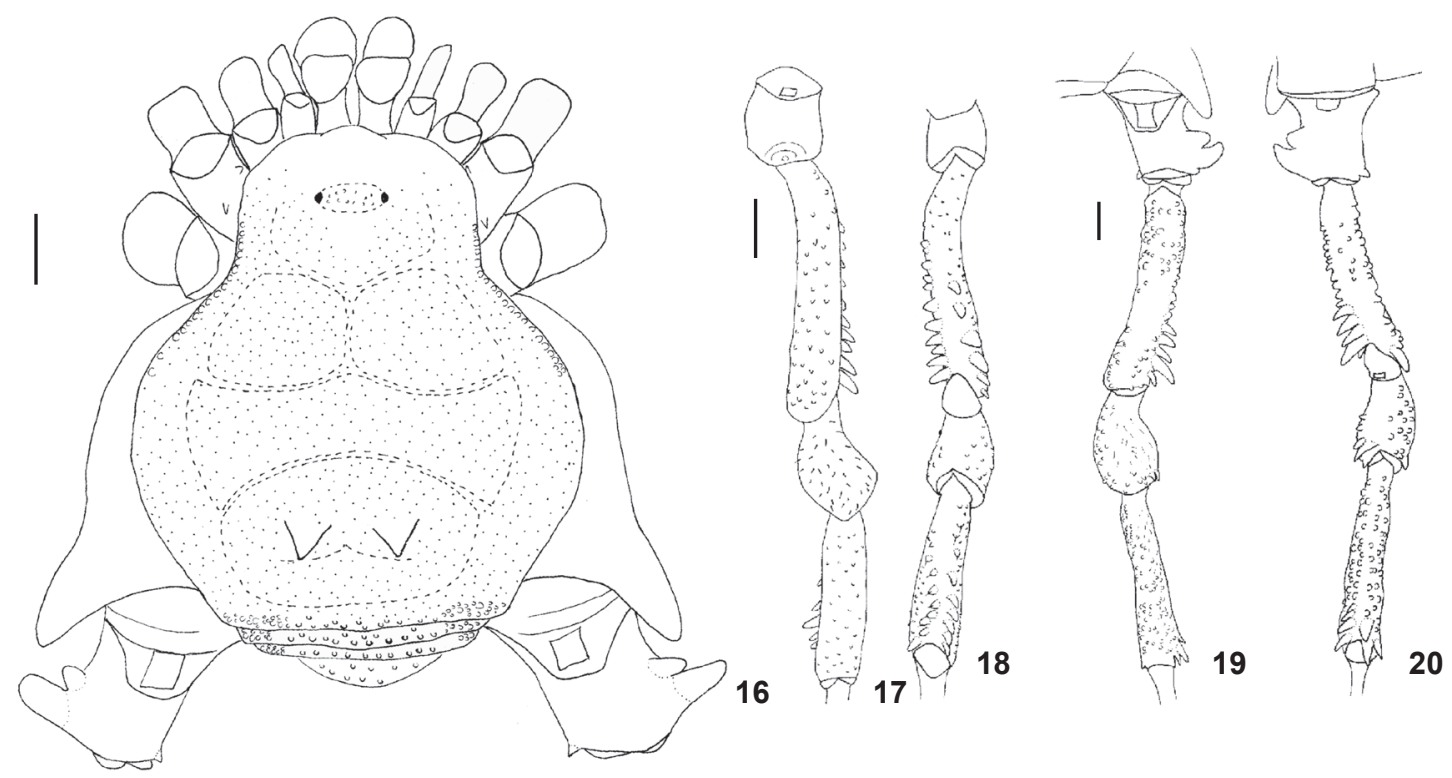

Figures 16-20. Fonckia sosia sp. nov., male holotype (MNHNCL): (16) dorsal habitus; (17) right trochanter-tibia III, dorsal view; (18) idem, ventral view; (19) right trochanter-tibia IV, dorsal view; (20) idem, ventral view. Scale bar: $1.0 \mathrm{~mm}$. 

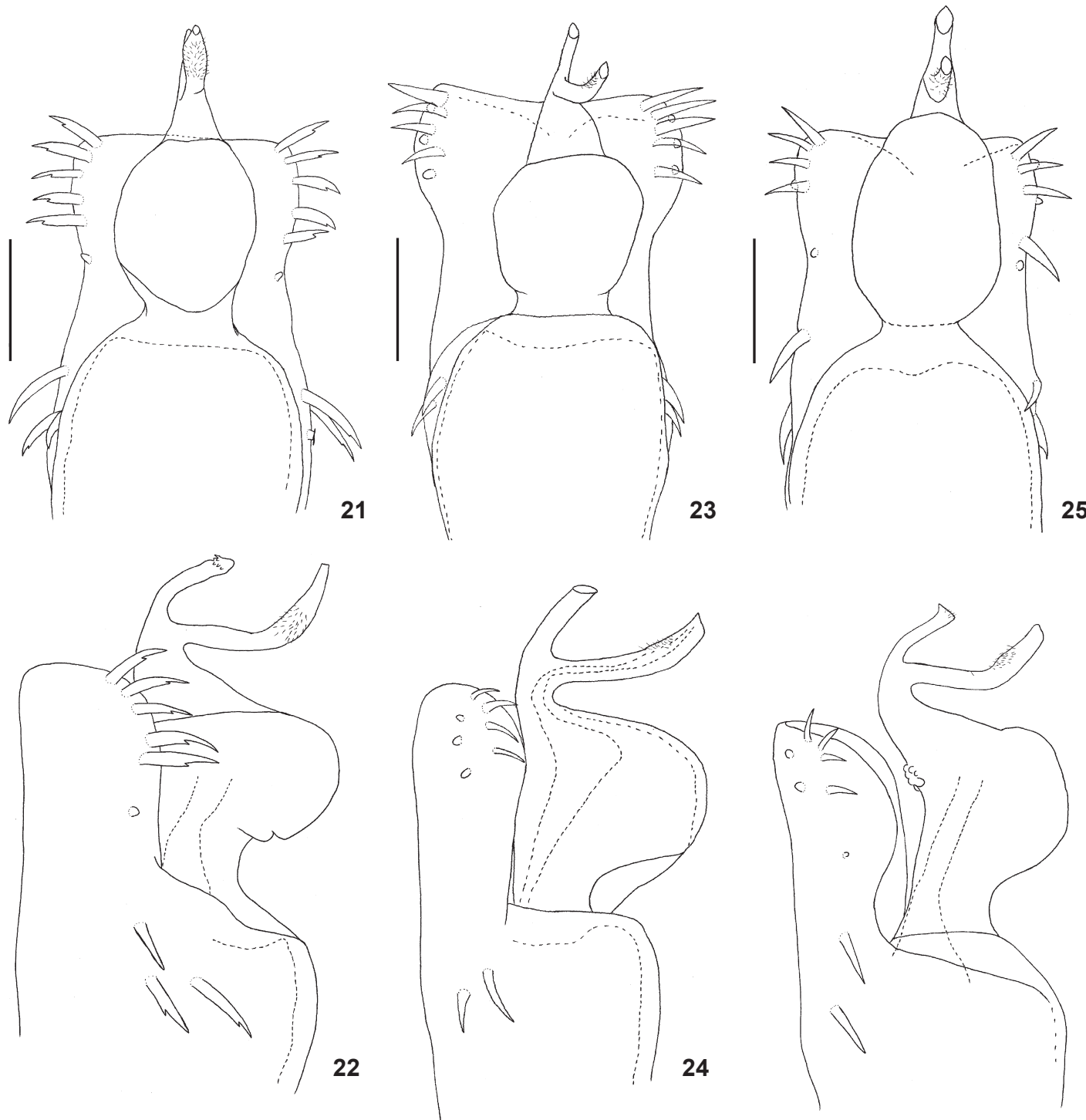

26

Figures 21-26. Fonckia spp. distal part of penis: (21-22) F. contulmo sp. nov. (holotype): (21) dorsal view, (22) right lateral view; (23-24) F. gallardoi (MZSP 36853): (23) dorsal view, (24) right lateral view; (25-26) F. sosia sp. nov. (holotype): (25) dorsal view, (26) right lateral view. Scale bar: $0.1 \mathrm{~mm}$.

area III with a parallel pair of paramedian spines, slightly curved backwards; IV slightly invading scutal area III. Scutal groove IV conspicuous only posteriorly between pair of spines on scutal area III. Lateral margin of dorsal scutum with a row of 20-23 whitish tubercles from ocularium to posterior region of scutal area I. Corners of posterior margin of dorsal scutum and free tergites I-II with a cluster of whitish tubercles among other small ones. Venter. Coxa I with a median row and posterior row of 5 , 3 tubercles, respectively; II-IV irregularly covered with small tubercles. Chelicerae. Segment I with 2 tubercles on bulla; II with 5 teeth; III with 4 teeth. Pedipalps. Coxa smooth; trochanter with a pair of ventral tubercles. Femur with 4-5 tubercles on basal 2/3. Patella with 2 small dorsal tubercles. Tibia with 8 dorsal tubercles, tibial setation: mesal iiiiI; ectal iil/iiil. Tarsal setation: mesal IIIi/Iiii; ectal IIIIi/III. Legs (Figs 17-20). Coxa IV covered with setiferous tubercles, its apophysis oblique. Trochanters I-II with 3, 2 enlarged ventral tubercles, respectively; II-III with 2 enlarged retrolateral tubercles; IV prolaterally with 1 conical median apophysis, 1 long apical apophysis, its apex curved anteriorly; retrolaterally with 1 enlarged apical tubercle. Femur III (Figs 17 and 18) with two ventral rows of tubercles increasing in size apically, becoming pointed; IV (Figs 19 and 20) ventrally 

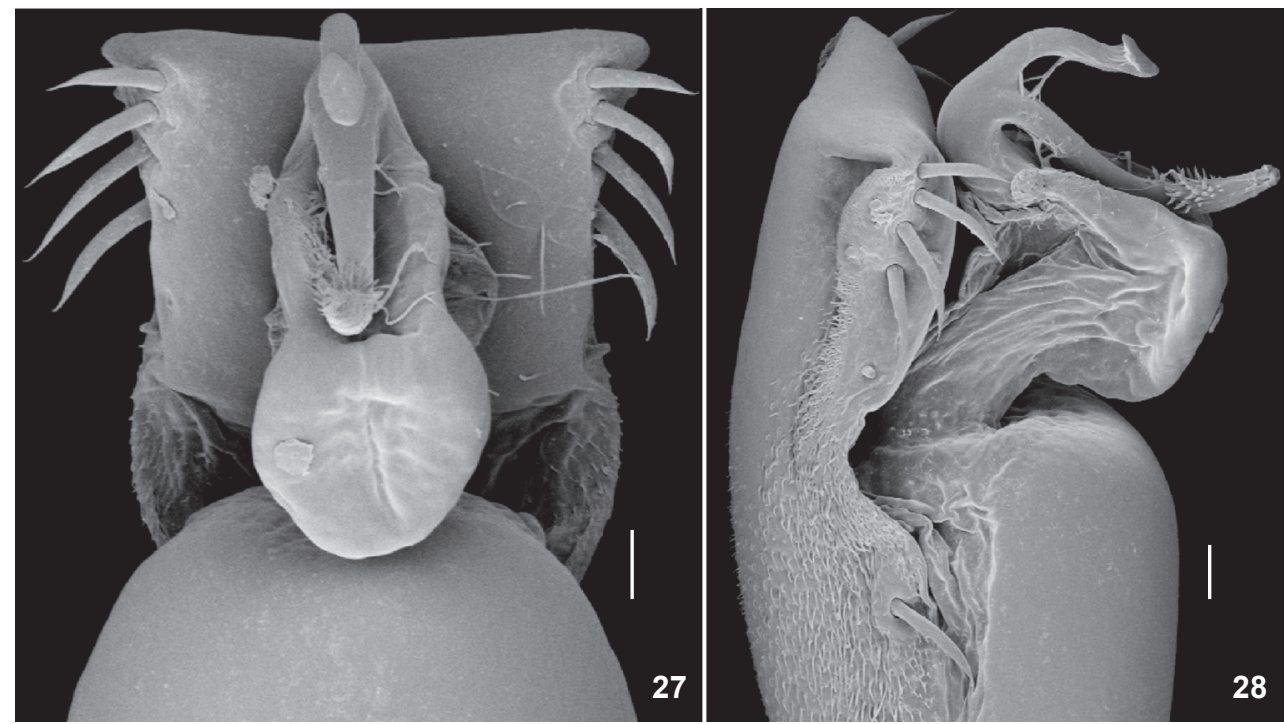

Figures 27-28. Fonckia processigera (MZSP 36853), distal part of penis: (27) dorsal view, (28) right lateral view. Scale bar: $0.01 \mathrm{~mm}$.

with two rows of tubercles, prolateral one increasing in size apically and largest, 2 apical spines. Patella IV (Figs 19 and 20) tuberculate, 3 enlarged proventral tubercles. Tibia IV (Figs 19 and 20) with two ventral rows of tubercles increasing in size apically (conspicuous in distal 1/4), 2 ventro-apical spines, 1 retrolateral apical spine, 2 enlarged, thin, short prolateral apical tubercles. Basitarsus I slightly inflated. Tarsal segmentation: 5, 8, 6, 6. Penis (Figs 25 and 26). Ventral plate with 4 pairs of unbranched distal setae, 2 pairs of rounded projections distal ventrally; 2 pairs of basal setae. Glans stylus with ventral projections on subdistal 1/4. Coloration (Fig. 29). Body and legs dark brown. Coxa IV, pair of paramedian spines on scutal area III and tubercles on trochanter IV black. Trochanters I-III, of the pedipalp, base of femora I-III, enlarged tubercles on legs III-IV, metatarsi-tarsi I-IV yellowish. Femur-patella IV light brown. Tubercles on lateral margin of dorsal scutum from ocularium to posterior region of scutal area I whitish. Size variation in males $(n=7)$. DSL 6.2-7.2, DSW 5.0-6.5, PrL 1.8-2.5, PrW 2.6-3.5, PpL 1.5-2.0, FIV 4.0-5.8. Female (MZSP 36830, Fig. 30): Posterior margin of dorsal scutum densely covered with fine granules. Spine of scutal area III smaller than in male. Trochanter IV with prolateral apophyses blunt and smaller than in male. Femora III-IV, patella-tibia IV with ventral rows of enlarged tubercles. Tarsal segmentation: 5, 7, 6, 6 . Pedipalpal tibia with 9 dorsal tubercles, tibial setation: mesal iiii// iiiI; ectal: ili; pedipalpal tarsal setation: mesal III; ectal IIIi. Measurements. DSL 6.1, DSW 5.9, PrL 1.9, PrW 2.6, PpL 1.5, FIV 3.7. Size variation in females $(\mathrm{n}=4)$. DSL 6.2-6.8, DSW 6.0-6.3, PrL 2.0-2.2, PrW 2.2-3.0, PpL 1.5-1.9, FIV 4.0-4.5.

Type material. ChiLe, IX Región de Araucanía: Malleco, Parque Nacional Conguillio, R. Pinto da Rocha, F. Cádiz L. \& D. Cádiz L. leg., 24-25.I.2010, male holotype \& 1 female paratype (MNHNCL). Paratypes: same data as holotype, 1 male, 2 females
(MZSP 36830); X Región de Los Lagos: Osorno, W. La Union, L. Peña leg., 25-28.III.1987, 4 males, 1 female (AMNH AK 285); Osorno, Pucatrihue, I.1971, 1 female, 1 ma (AMNH); 27 30.I.1978, 1 female (AMNH); 11.XII.1980, 1 female (AMNH); XIV Región de Los Rios: Valdivia, Los Troncos, L. Peña leg., III.87, 1 male (AMNH AK 315).

Type locality. Chile, IX Región de Araucanía: Malleco, Parque Nacional Conguillio (Fig. 33).

Etymology. Sosia is a noun in apposition, which means very similar persons in Portuguese/Spanish, in reference to its close resemblance to Fonckia gallardoi.

Remarks. Relationships of Fonckia: KuRY (2003) transferred Fonckia, which was originally placed in Gonyleptinae, to Pachylinae, without justifying it. Regardless, the systematics of both subfamilies is outdated, and needs to be studied and revised to comply with modern standards. The monophyly of Gonyleptinae, which includes harvestmen with three scutal areas and without other remarkable characteristics, has not been tested in the context of a morphological cladistic analysis. The same is valid for Pachylinae, diagnosed by the presence of four scutal areas. Preliminary results of an ongoing phylogenetic analysis, previously mentioned in PINTO-DA-RochA et al. (2012), indicate that, among other features, the male genitalia of Gonyleptinae species has a deep cleft on the ventral plate, which is absent in Pachylinae. Because specimens of Fonckia lack this cleft on the plate, the correct placement of the genus is in the latter subfamily, and further comments regarding its closest relatives are given below. Pachylinae is the largest subfamily of Gonyleptidae and no phylogenies including all or most pachyline taxa have been proposed (128 genera, ca. 399 spp.). The available gonyleptid phylogenies include only a few pachylines in the outgroup (PINTO-DA-ROCHA 2002, HARA \& PINTO- 

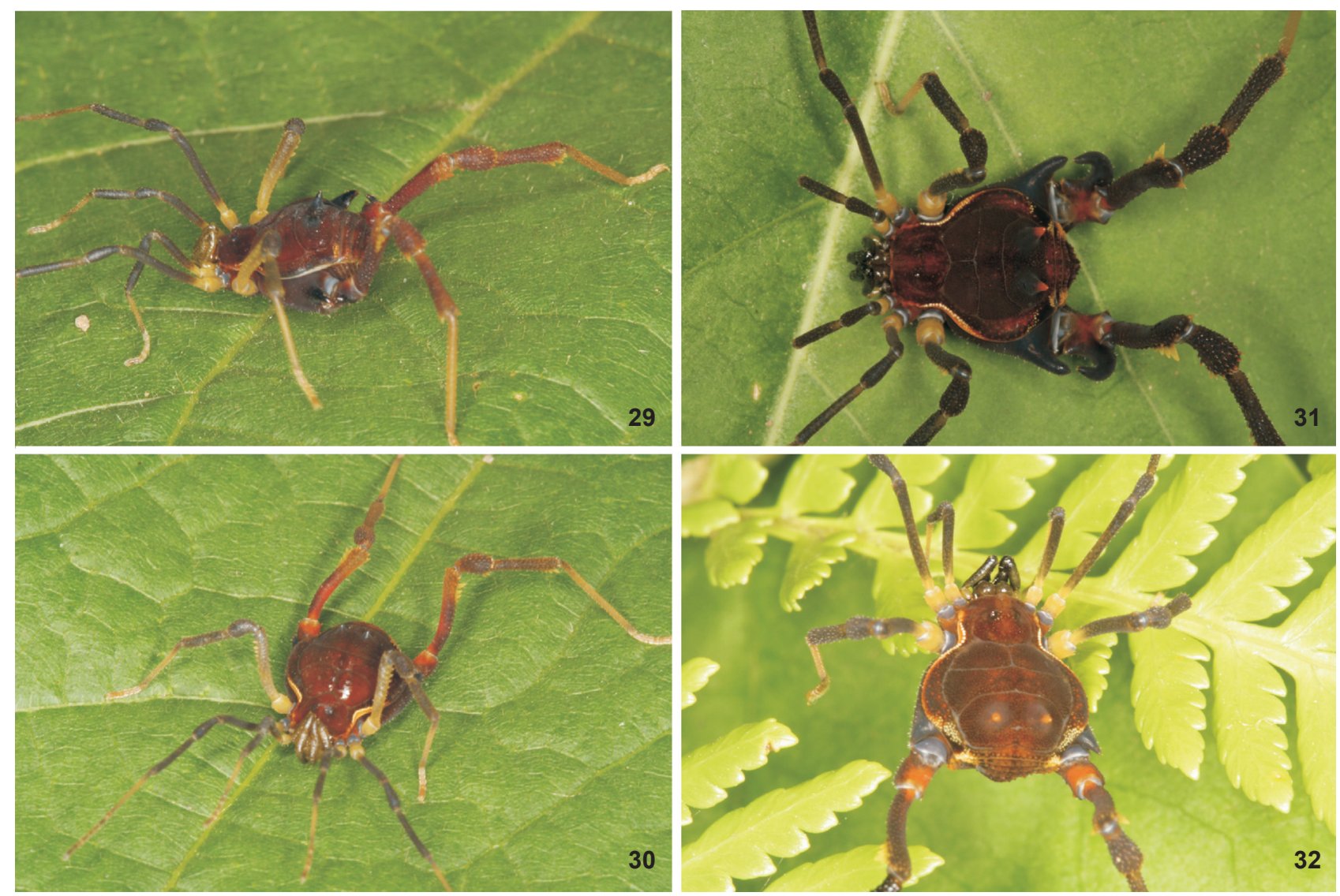

Figures 29-32. Fonckia spp., live specimens: F. sosia sp. nov.,: (29) male; (30) female; F. gallardoi: (31) male; (32) female.

Da-Rocha 2010, DaSilva \& Pinto-da-Rocha 2010, Mendes 2011, Bragagnolo \& Pinto-Da-Rocha 2012, Hara et al. 2012). The most comprehensive phylogenetic hypothesis for the family is that of Pinto-Da-Rocha (2002). According to at least two ongoing studies of the supraspecific phylogeny of gonyleptids, Pachylinae is a polyphyletic assemblage (according to at least two ongoing studies of the supraspecific phylogeny of gonyleptids). However, because none of those analyses include Fonckia, we do not know how it relates to the other Pachylinae genera. Furthermore, the monophyly of many genera placed in Pachylinae is not well supported (but see exceptions in HarA \& Pinto-da-Rocha 2010, Bragagnolo \& Pinto-da-Rocha 2009), which adds another level of uncertainty to the issue. The presence of a relatively short row of beige to whitish tubercles on the lateral margin of the dorsal scutum (from the ocularium to approximately the middle of scutal area I), as far as we know, is unique to Fonckia and we suggest this character as a putative synapomorphy for the genus. The cluster of tubercles on the posterior corners of the dorsal scutum is a possible additional putative synapomorphy of Fonckia. If this hypothesis is correct, the absence of this feature in $F$. processigera needs to be interpreted as a reversal. Alternatively, this character may be interpreted as a synapomorphy of the remaining three species (F. contulmo sp. nov., F. gallardoi and F. sosia sp. nov.). The prolateral apophyses on trochanter IV of males of Fonckia (a median conical apophysis and one long, robust apical apophysis) resemble the condition found in many Chilean genera such as Eubalta Roewer, 1923, Chilegyndes Roewer, 1961 and Metagyndes Roewer, 1913 and some Southeastern Brazilian genus such as Graphinotus Koch, 1839 and even a species of Eusarcus Perty, 1833 (E. armatus). Up to now, we only have information regarding the male genitalia of Metagyndes, Graphinotus (unpublished data) and Eusarcus (Hara \& PINTO-DARосна 2010), none of which resemble the male genitalia of Fonckia. The latter presents some interesting characteristics, such as the glans projected dorsally, stylus and ventral processes strongly curved dorsally and apex abruptly truncated, which are shared with another set of Chilean genera: Neogonyleptes Roewer, 1913, Sadocus Sørensen, 1886 and possibly Spinivunus Roewer, 1943. Considering all the evidence gathered thus far, it seems that Fonckia is more closely related with the Chilean genera. However, the available data does not al- 


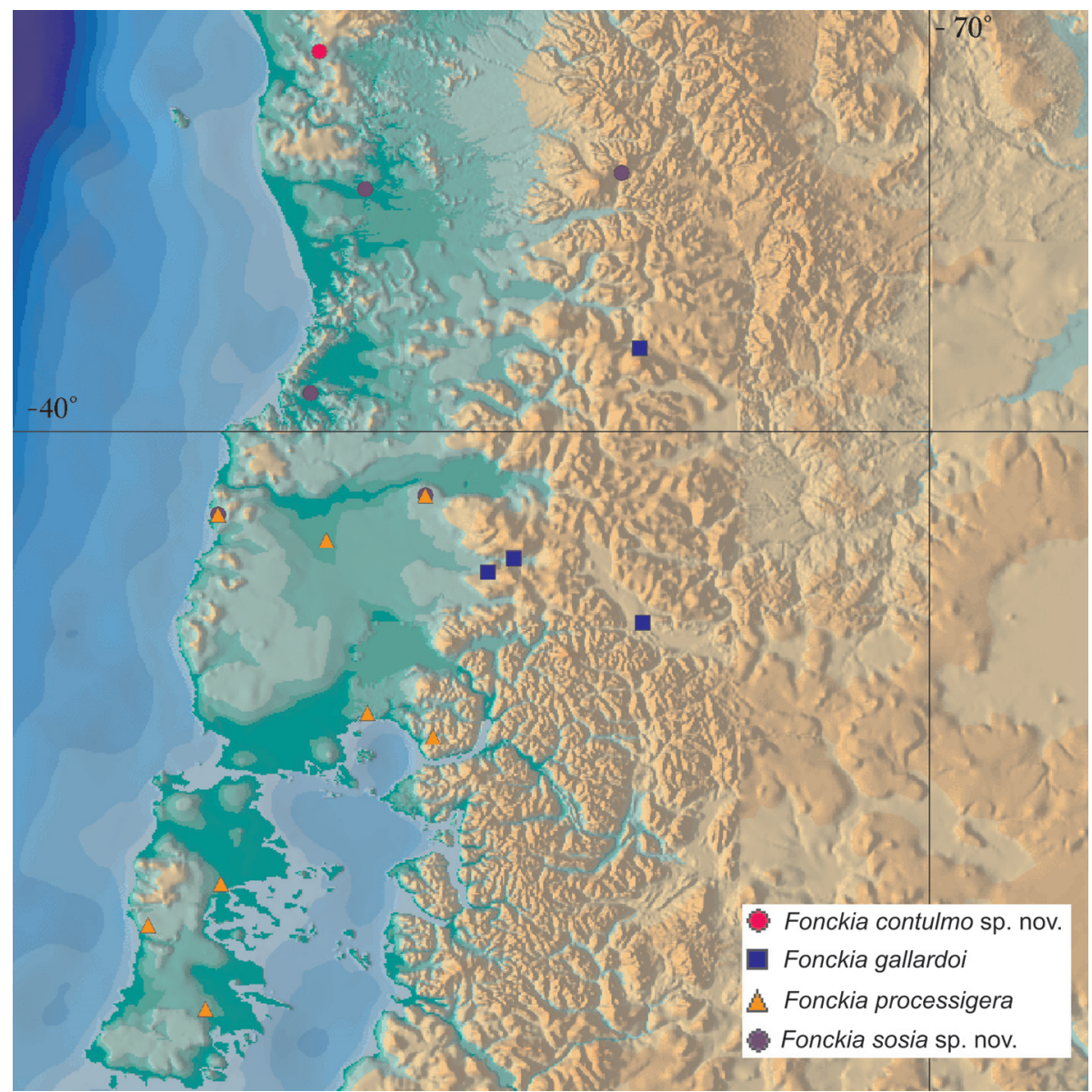

Figure 33. Records of distribution of Fonckia spp. in Chile and Argentina.

low us to precisely indicate which genus or group of Chilean genera is closest to Fonckia. A comprehensive cladistic analysis, including as many pachylinean genera (especially Chilean ones) as possible, should be performed to test the putative synapomorphies of Fonckia and its phylogenetic relationships, but this was not the focus of our study.

Distribution (Fig. 33). The four species of Fonckia are endemic of a small region from $38^{\circ} \mathrm{S}$ (F. contulmo sp. nov.) to $43^{\circ} \mathrm{S}$ (F. processigera), and $71^{\circ} \mathrm{W}$ (F. gallardoi) to $74^{\circ} \mathrm{W}$ (F. processigera), in Valdivian Temperate Rain Forest of Chile (F. contulmo sp. nov., F. processigera, F. sosia sp. nov.) and in a small part of SW Argentina close to Chilean border (F. gallardoi). They were recorded in vegetational subtypes of Evergreen Valdivian forests, Alerce Forest (Fitzroya cupressoides), and Nothofagus Forest. They occur in the Codillera Costera (F. contulmo sp. nov., F. sosia sp. nov.), in the Andean Cordillera (F. processigera, F. gallardoi) and in lowland of Chilean Central Valley between them ( $F$. processigera). The Valdivian Temperate Rain Forest (see CAVELIER $\&$ TeCKLIn 2005) encompasses most of Chilean Opiliones diver- sity. As Chilean opilionids are scarce in arachnid collections (see our small sample studied) we think that it would be premature to associate Chilean species with local vegetation physiognomies.

\section{LITERATURE CITED}

Acosta, L.E. \& E.A. Maury. 1998. Opiliones, p. 569-580. In: J.J. Morrone \& S. CosCARÓn (Eds). Biodiversidad de artropodos argentinos, Una perspectiva biotaxonómica. La Plata, Ediciones Sur, 580p.

Acosta, L.E.; A. Pérez-Gonzalez \& A.L. Tourinho. 2007. Methods and Techniques of Study: Methods for taxonomic study, p. 494-505. In: G. Machado; R. Pinto-Da-Rocha \&. G. Giribet (Eds). Harvestmen, the biology of Opiliones. Cambridge, Harvard University Press.

Bragagnolo, C. \& R. Pinto-Da-Rocha. 2009. Review of the Brazilian harvestman genus Roeweria Mello-Leitão, 1923 (Opiliones: Gonyleptidae). Zootaxa 2270: 39-52. 
Bragagnolo, C. \& R. Pinto-DA-Rocha. 2012. Systematic review of Promitobates Roewer, 1913 and cladistic analysis of Mitobatinae Simon, 1879 (Arachnida: Opiliones: Gonyleptidae). Zootaxa 3308: 1-48.

Canals, J. 1934. Opiliones de la Argentina. Descripción de "Diconospelta Gallardoi", n. gen., n. sp., y nómina de otros opiliones, nuevos para nuestro país. Estudios aracnológicos (V) - Talleres gráficos de "Caras y Caretas". Buenos Aires, 10p.

Canals, J. 1936. Los Opiliones de Chile. Revista Chilena de Historia Natural 39: 68-71.

Cavelier, J. \& D. Tecklin. 2005. Conservación de la Cordellera de la Costa: un desafío urgente en la ecorregión valdiviana, p. 632641. In: C. Smith-Ramírez; J.J. Armesto \& C. Valdovinos (Eds). Historia, biodiversidad y ecología de los bosques costeros de Chile. Santiago, Editorial Universitaria Bosque Nativo.

Ceralovic-K., T.N. 1985. Catálogo de los Opiliones de Chile (Arachnida). Boletin de la Sociedad de Biologia de Concepción 56: 7-29.

DaSilva, M.B. \& P. GNASPINI. 2009. A systematic revision of Goniosomatinae (Arachnida: Opiliones: Gonyleptidae), with a cladistic analysis and biogeographical notes. Invertebrate Systematics 23: 530-624.

DaSilva, M.B. \& R. Pinto-DA-Rocha. 2010. Systematic review and cladistic analysis of the Hernandariinae (Opiliones: Gonyleptidae). Zoologia 27 (4): 577-642.

Galiano, M.E. \& E.A. Maury. 1979. Lista de los ejemplares tipicos de "Arachnida" (Opiliones, Scorpiones y Solifugae) depositados en le Museo Argentino de Ciencias Naturales "Bernardino Rivadavia". Revista del Museo Argentino de Ciencias Naturales "Bernardino Rivadavia" y Instituto Nacional de Investigación de las Ciencias Naturales, Entomología, 5 (11): 301-334.

Hara, M.R. \& R. Pinto-Da-Rocha. 2010. Systematic review and cladistic analysis of the genus Eusarcus Perty 1833 (Arachnida, Opiliones, Gonyleptidae). Zootaxa 2698: 1-136.

Hara, M.R.; R. Pinto-da-Rocha \& A.B. Kury. 2012. Revision of Nanophareus, a mysterious harvestman genus from Chile, with descriptions of three new species (Opiliones: Laniatores: Gonyleptidae). Zootaxa 3579: 37-66.

KuRY, A.B. 2003. Annotated catalogue of the Laniatores of the New Word (Arachnida, Opiliones). Revista Ibérica de Aracnologia 1: 5-337.

Mello-Leitão, C.F. 1926. Notas sobre os Opiliones laniatores sulamericanos. Revista do Museu Paulista 14: 1-59.

Mello-Leitão, C.F. 1935. Algumas notas sobre os Laniatores. Ar- quivos do Museu Nacional do Rio de Janeiro 36 (4): 87-116. Mello-Leitão, C.F. 1931. Opiliões novos ou criticos. Archivos do Museu Nacional do Rio de Janeiro 33 (3): 117-148.

Mello-Leitão, C.F. 1932. Opiliões do Brasil. Revista do Museu Paulista 17 (2): 1-505.

Mello-Leitão, C.F. 1935. Algumas notas sobre os Laniatores. Archivos do Museu Nacional 36 (4): 87-116.

Mello-Leitão, C.F. 1946. Nuevos arácnidos sudamericanos de las colecciones del museo de Historia Natural de Montevideo. Comunicaciones zoologicas del Museo de Historia natural de Montevideo 2 (35): 1-10.

Mendes, A.C. 2011. Phylogeny and taxonomic revision of Heteropachylinae (Opiliones: Laniatores: Gonyleptidae). Zoological Journal of the Linnean Society 163: 437-483.

Moritz, M. 1971. Die Typen der Arachniden-Sammlung der zoologischen Museums Berlin I. Opiliones. Mitteilungen aus dem Zoologischen Museum in Berlin 47 (1): 189-214.

PINTO-DA-Rocha, R. 1997. Systematic review of the neotropical family Stygnidae (Opiliones, Laniatores, Gonyleptoidea). Arquivos de Zoologia 33 (4): 163-342.

PINTO-DA-Rocha, R. 2002. Systematic review and cladistic analysis of the Caelopyginae (Opiliones: Gonyleptidae). Arquivos de Zoologia 36 (4): 357-464.

Pinto-Da-Rocha, R.; G. Machado, \& G. Giribet. 2007. Harvestmen, the biology of Opiliones. Cambridge, Harvard University Press.

Pinto-Da-Rocha, R.; A.R. Benedetti; E.G. Vasconcelos \& M.R. Hara. 2012. New systematic assignments in Gonyleptoidea (Arachnida, Opiliones, Laniatores). ZooKeys 198: 25-68.

Ringuelet, R.A. 1959. Los aracnidos Argentinos del orden Opiliones. Revista del Museo Argentino de Ciencias Naturales "Bernardino Rivadavia", Ciencias Zoologicas, 5 (2): 127-439.

Roewer, C.F. 1913. Die Familie der Gonyleptiden der OpilionesLaniatores. Archiv für Naturgeschichte 79A (5): 1-256.

Roewer, C.F. 1923. Die Weberknechte der Erde. Systematische Bearbeitung der bisher bekannten Opiliones. Jena, Gustav Fischer.

Roewer, C.F. 1930. Weitere Weberknechte IV. (4. Ergänzung der Weberknechte der Erde, 1923). Abhandlungen der Naturwissenschaftlichen Verein zu Bremen 27 (3): 341-452.

Soares, B.A.M. \& H.E.M. Soares. 1949. Monografia dos gêneros de opiliões neotrópicos II. Arquivos de zoologia do Estado de São Paulo 7 (2): 149-240.

Sørensen, W. 1902. Gonyleptiden (Opiliones, Laniatores). Ergebnisse der Hamburger Magalhaensischen Sammelreise 6 (5): 1-36.

Submitted: 01.VIII.2012; Accepted: 07.III.2013.

Editorial responsibility: Antonio D. Brescovit 